\title{
Marek Szajt
}

Politechnika Częstochowska

e-mail: marek.szajt@wz.pcz.pl

\section{AKTYWNOŚĆ PATENTOWA A STRUKTURA \\ DEMOGRAFICZNA - ANALIZA REGIONALNA}

PATENT ACTIVITY VS. DEMOGRAPHIC STRUCTURE REGIONAL ANALYSIS

DOI: $10.15611 / \mathrm{pn} .2018 .517 .10$

JEL Classification: R11, O32, J11

Streszczenie: Celem badań prezentowanych w artykule było wskazanie kierunku i siły oddziaływania czynników demograficznych na aktywność patentową na poziomie regionalnym. W badaniu wykorzystano dane statystyczne pochodzące z Eurostatu, dotyczące regionów Unii Europejskiej (28). Poza często przedstawianymi w literaturze determinantami, takimi jak zasoby ludzkie dla nauki i techniki, personel i badacze zatrudnieni w sektorze B+R czy nakłady na działalność $\mathrm{B}+\mathrm{R}$, pod uwagę wzięto też czynniki demograficzne. Proponowane $\mathrm{w}$ dotychczasowych pracach modele innowacyjności wzbogacono o zmienne demograficzne, których istotność powinna wskazywać na znaczenie danych czynników. Jako czynniki demograficzne potraktowano bezpośrednio (dzięki dostępności danych) płeć i pośrednio wiek oraz wykształcenie. Zgodnie z oczekiwaniami w badaniach potwierdzono, iż wzrost poziomu wykształcenia istotnie wpływa na wzmocnienie innowacyjności regionów w przeciwieństwie do wydłużenia czasu życia.

Słowa kluczowe: innowacyjność, region, demografia, płeć.

Summary: The research presented in this paper was aimed at identifying the direction and force of demographic factors impact on patent activity at the regional level. The study used statistical data from Eurostat concerning the regions of the European Union (28). In addition to the often identified determinants such as human resources for science and technology, $R$ \& D staff and researchers, or R\&D expenditure, demographic factors were also taken into account. The innovativeness models proposed in the previous works have been enriched with demographic variables, whose relevance should indicate the relevance of the factors. As demographic factors were treated directly (via data availability): gender, age and education. As expected in the studies, it was confirmed that the increase in educational attainment significantly influenced the strengthening of the innovativeness of the regions as opposed to the prolongation of life time.

Keywords: innovation, region, demography, gender. 


\section{Wstęp}

W badaniach nad innowacyjnością jako jeden z jej mierników wykorzystuje się aktywność patentową. Na poziomie makro i na poziomie regionalnym, obok klasycznych już determinant innowacyjności, jak finanse i czynnik ludzki, wskazuje się również na istnienie innych, trudno definiowalnych lub trudno mierzalnych, często związanych z kształtowaniem gospodarki, lecz w sposób nie bezpośredni. Do determinant tych niewątpliwie należą czynniki demograficzne. Przy tym ich ujęcie oraz siła oddziaływania mogą być bardzo różne w odniesieniu do innych mierzonych kategorii wynikowych. Celem niniejszej pracy było wskazanie wpływu (braku wpływu) wybranych czynników demograficznych na aktywność patentową na poziomie regionalnym w Unii Europejskiej. Pod uwagę w badaniu wzięto takie zmienne, jak płeć (także w odniesieniu do personelu zatrudnionego w sektorze $\mathrm{B}+\mathrm{R}$ ), wiek, wyksztalcenie. Wskazane zmienne demograficzne mierzone są kilkoma sposobami. Jeżeli chodzi o wiek, jest to mediana wieku oraz proporcje grup wiekowych względem siebie (np. osób w wieku do 19 lat względem osób powyżej 19 lat). Wykształcenie mierzone jest zwykle jako pewien wskaźnik skolaryzacji obrazujący udział osób mających dany poziom wykształcenia w ogóle osób lub mierzących udział osób wykształconych w konkretnych grupach wiekowych.

Zróżnicowanie aktywności innowacyjnej na poziomie regionalnym wskazywane jest w wielu publikacjach [Szajt 2013b; Zawada, Herbuś 2014]. Jako jego powody wymienia się różnice w poziomie finansowania, w strukturze gospodarczej różnych obszarów, głównych nurtach rozwoju regionów czy zasobach ludzkich [Janasz, Kozioł 2007]. Ostatni z czynników opisywany jest zwykle węziej - obejmuje badaczy (lub personel) zatrudnionych w sektorze $\mathrm{B}+\mathrm{R}$, a w ostatnim czasie częściej również zasoby ludzkie dla nauki i techniki [Ostraszewska, Tylec 2017; Szajt 2013a]. Aktywność innowacyjna, mająca w swej istocie czynnik twórczy, nie może się jednak obyć bez człowieka. Występuje on w dwojakiej roli: z jednej strony twórcy, z drugiej odbiorcy, konsumenta. Zarówno od twórców, jak i odbiorców wymaga się pewnych kompetencji lub przymiotów. Twórcy traktowani są jako osoby odpowiednio wykształcone i posiadające odpowiedni poziom doświadczenia, które to przez odpowiednią pracę są w stanie przełożyć na nowy produkt oferowany konsumentom. Z kolei od konsumentów wymaga się z jednej strony kompetencji wymaganych do zrozumienia funkcjonalności i korzystania z nowych produktów, z drugiej strony otwartości na nowości, chęci zmian i polepszenia swojej egzystencji. W związku z tym warte zainteresowania wydaje się prześledzenie potencjalnego wpływu czynników demograficznych na kształtowanie się innowacyjności na poziomie regionalnym. 


\section{Wykształcenie mieszkańców Unii Europejskiej - ujęcie regionalne}

Zróżnicowanie poziomu innowacyjności oraz jej determinant jest faktem. Należy jednak postawić pytanie, jak ma się do tego struktura demograficzna.

Analizując wyksztalcenie mieszkańców Europy, obserwujemy silny wzrost udziału osób z wykształceniem wyższym w liczbie mieszkańców. Obecnie w państwach uznawanych za najbardziej innowacyjne poziom ten sięga nieco ponad $40 \%$ dla osób aktywnych zawodowo, przy średnim poziomie w Unii około 30\% (30,7\%). Zmiana jest wyraźna. W ciągu lat 2000-2016 udział ten wzrósł z poziomu około 19,5\%. Największy wzrost odnotowano dla Malty (272\%), Portugalii (172\%) i Polski (152\%). Jedynie na Litwie zaobserwowano spadek tego wskaźnika (-6\%) w badanych latach, ale jest to raczej skutek depopulacji będącej efektem emigracji zarobkowej w dużej mierze osób mających perspektywy - wysoko wykształconych, których udział i tak jest wysoki $(39,7 \%)$. Warto również podkreślić, że dziś, prócz wykształcenia wyższego, coraz większego znaczenia nabiera wykształcenie średnie, techniczne i zawodowe, które są nieodzownym elementem rozwoju technologicznego przedsiębiorstw [Turek 2016].

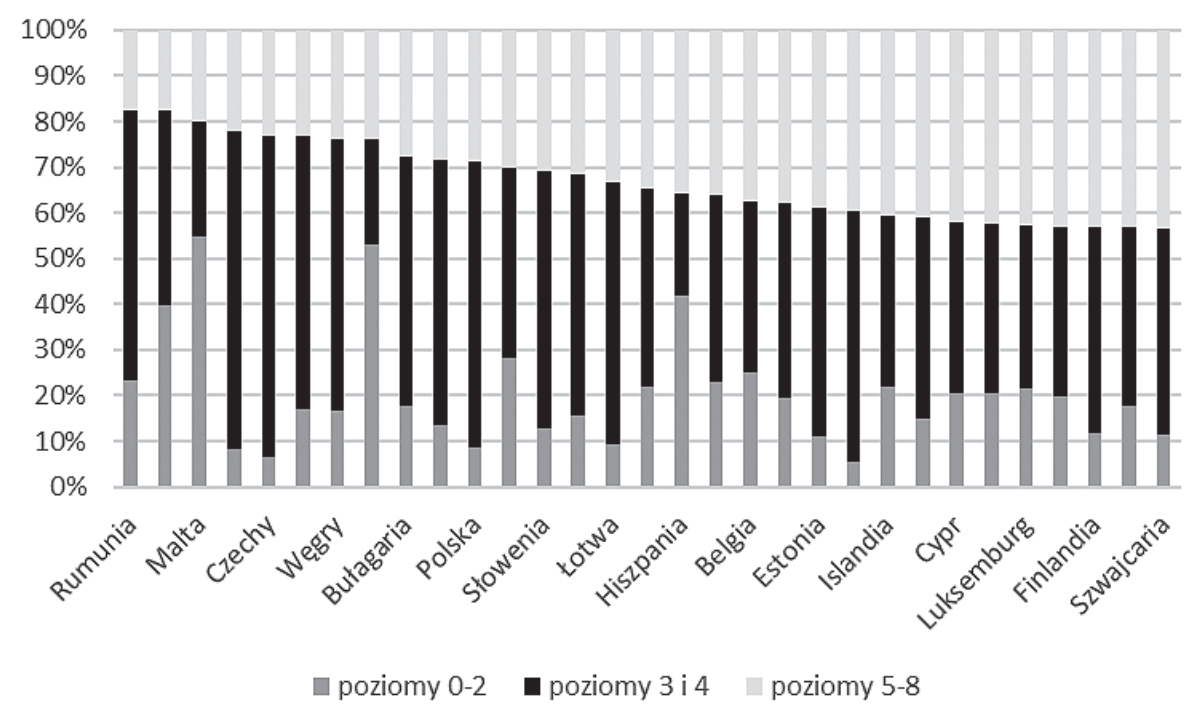

Rys. 1. Struktura mieszkańców państw europejskich względem poziomu wykształcenia Źródło: opracowanie własne na podstawie danych Eurostat.

$\mathrm{W}$ analizach zatrudnienia w sektorze $\mathrm{B}+\mathrm{R}$ często pod uwagę bierze się również zatrudnionych techników traktowanych niemal na równi z badaczami. W tym ujęciu wzrost poziomu wykształcenia w państwach europejskich jest również znaczny i wynosi dzisiaj 77\% (przy 64,4\% w roku 2000). Najszybszy wzrost wskaźnika 
wykształcenia na poziomie 3-8 w Europie zanotowano dla Malty (148\%) i Portugalii (144\%), co i tak pozwoliło osiągnąć tym państwom wyniki najsłabsze w Europie, odpowiednio 45,2\% i 47,0\% aktywnych zawodowo o tym poziomie wykształcenia. Poniżej 75\% wskaźnik ten mają jeszcze Hiszpania (58,3\%), Włochy (60,1\%) i Grecja $(71,8 \%)$. Liderem jest wspominana wcześniej Litwa ze wskaźnikiem wynoszącym 94,6\%, za nią są Czechy (93,5\%), Słowacja (91,9\%) i Polska (91,3\%). Warto nadmienić, iż poziom wykształcenia jest w przypadku aktywności patentowej traktowany jako determinanta - stymulanta. Przeprowadzone testy to potwierdzają. Państwa posiadające powyżej $25 \%$ społeczeństwa z jedynie I stopniem wykształcenia charakteryzują się istotnie niższym $(t=-3,452 ; p=0,001)$ względem pozostałych wskaźnikiem aktywności patentowej - stanowi on jedynie średnio 53\% aktywności pozostałych. $\mathrm{Z}$ kolei analiza w drugim ujęciu wskazuje, że państwa posiadające powyżej $25 \%$ społeczeństwa z IV stopniem wykształcenia charakteryzują się istotnie wyższym $(t=4,403 ; p<0,001)$ względem pozostałych wskaźnikiem aktywności patentowej stanowi on średnio $220 \%$ aktywności pozostałych.

Tabela 1. Średni udział osób z wykształceniem wyższym wśród aktywnych zawodowo oraz wartości wskaźników konwergencji w tym zakresie w państwach Unii Europejskiej

\begin{tabular}{|l|c|c|c|c|c|c|}
\hline \multicolumn{1}{|c|}{ Państwo } & $\theta$ & $\beta$ & $p$ & $\begin{array}{c}\text { Średnia } \\
(\mathrm{w} \%)\end{array}$ & $\begin{array}{c}\text { Średnia } \\
2016 \\
(\mathrm{w} \%)\end{array}$ & $\begin{array}{c}\text { Zmiana } \\
\text { średnioroczna } \\
(\mathrm{w} \%)\end{array}$ \\
\hline Austria & 2 & 3 & 4 & 5 & 6 & 7 \\
\hline Belgia & $-3,166$ & 0,043 & 0,019 & 15 & 29 & 5,4 \\
\hline Bułgaria & $-2,160$ & 0,018 & 0,059 & 24 & 33 & 2,1 \\
\hline Chorwacja & 0,284 & $-0,005$ & 0,791 & 15 & 24 & 3,0 \\
\hline Cypr & - & - & - & 13 & 20 & 3,1 \\
\hline Czechy & - & - & - & 22 & $\mathbf{3 8}$ & 3,4 \\
\hline Dania & $-1,682$ & 0,014 & 0,144 & 10 & 21 & 5,0 \\
\hline Estonia & $-0,246$ & 0,002 & 0,811 & 22 & 31 & 2,2 \\
\hline Finlandia & - & - & - & 24 & 34 & 2,2 \\
\hline Francja & $-0,995$ & 0,009 & 0,424 & 27 & $\mathbf{3 6}$ & 1,8 \\
\hline Grecja & $-2,456$ & 0,030 & 0,023 & 20 & 31 & 2,8 \\
\hline Hiszpania & $-0,813$ & 0,008 & 0,434 & 14 & 26 & 4,0 \\
\hline Holandia & $-1,754$ & 0,013 & 0,100 & 21 & 33 & 2,7 \\
\hline Irlandia & $-2,672$ & 0,018 & 0,023 & 21 & 31 & 2,6 \\
\hline Litwa & - & - & - & 19 & $\mathbf{3 8}$ & 4,3 \\
\hline Luksemburg & - & - & - & 35 & 34 & $-0,2$ \\
\hline Lotwa & - & - & - & 15 & 30 & 4,3 \\
\hline Malta & - & - & - & 5 & 19 & 8,8 \\
\hline
\end{tabular}


Tabela 1, cd.

\begin{tabular}{|l|c|c|c|c|c|c|}
\hline \multicolumn{1}{|c|}{1} & 2 & 3 & 4 & 5 & 6 & 7 \\
\hline Niemcy & $-4,335$ & 0,161 & 0,000 & 21 & 24 & 0,8 \\
\hline Polska & $-2,228$ & 0,045 & 0,048 & 9 & 25 & 6,5 \\
\hline Portugalia & $-1,974$ & 0,063 & 0,187 & 8 & 22 & 6,8 \\
\hline Rumunia & $-0,786$ & 0,010 & 0,462 & 8 & 15 & 4,5 \\
\hline Słowacja & $-14,510$ & 0,040 & 0,005 & 8 & 20 & 5,6 \\
\hline Słowenia & - & - & - & 13 & 27 & 4,8 \\
\hline Szwecja & $-2,583$ & 0,031 & 0,042 & 27 & 35 & 1,7 \\
\hline Węgry & $-0,101$ & 0,001 & 0,924 & 12 & 21 & 3,6 \\
\hline Wlk. Brytania & $-4,643$ & 0,020 & 0,000 & 26 & 38 & 2,5 \\
\hline Włochy & $-1,500$ & 0,017 & 0,152 & 8 & 16 & 4,2 \\
\hline UE & $-8,977$ & 0,056 & 0,000 & 17 & 27 & 3,0 \\
\hline
\end{tabular}

Źródło: opracowanie własne na podstawie danych Eurostat.

Tabela 2. Wartości współczynników korelacji pomiędzy stopniem feminizacji zasobów ludzkich dla nauki i techniki a poziomem aktywności patentowej

\begin{tabular}{|c|c|c|c|c|c|}
\hline Państwo & $r_{x y}$ & Państwo & $r_{x y}$ & Państwo & $r_{x y}$ \\
\hline Holandia & $-4,846^{*}$ & Węgry & 0,217 & Grecja* & 3,488 \\
\hline Finlandia & $-3,766^{*}$ & Belgia & 0,683 & Austria & $3,531 *$ \\
\hline Chorwacja & $-3,655^{*}$ & Eotwa & 0,809 & Dania & $3,533^{*}$ \\
\hline Portugalia & $-2,335^{*}$ & Rumunia & 0,841 & Słowenia & $4,757^{*}$ \\
\hline Irlandia & $-2,084 *$ & Malta & 0,972 & Hiszpania & $5,764^{*}$ \\
\hline Luksemburg & $-1,805$ & Cypr & 1,407 & Szwecja & $6,158^{*}$ \\
\hline Francja & $-1,785$ & Estonia & 1,485 & Bułgaria & $9,563^{*}$ \\
\hline Wlk. Brytania & $-0,789$ & Litwa & 1,807 & Słowacja & $17,243^{*}$ \\
\hline Polska & $-0,55$ & Włochy* & 2,191 & & \\
\hline Niemcy & $-0,486$ & Czechy* & 3,247 & & \\
\hline
\end{tabular}

Źródło: opracowanie własne na podstawie danych Eurostat.

W ośmiu z badanych 19 państw obserwujemy konwergencje regionalną w zakresie poziomu wyksztalcenia aktywnych zawodowo. Dotyczy to zwłaszcza państw Europy środkowej oraz Wielkiej Brytanii i Szwecji. W przypadku pięciu państw (Luksemburg, Wielka Brytania, Cypr, Irlandia i Finlandia) co najmniej 35\% aktywnych zawodowo ma wykształcenie wyższe. Najsłabiej pod tym względem wypadają Włochy (16\%), Rumunia (15\%) i Malta (19\%). Co ważne, dotychczasowe tempo zmian (poza Maltą) w tych państwach nie gwarantuje wyraźnej zmiany w najbliższym czasie. Ich obecny poziom jest zbliżony do poziomu średniego dla Unii sprzed 16 lat. Pamiętać należy, 
że jako czynnik w przyszłości wzmacniający potencjał absorpcyjny dla innowacji poziom wykształcenia może odgrywać coraz ważniejszą rolę.

Kolejnym czynnikiem, który mógłby wpłynąć na poziom aktywności innowacyjnej, jest płeć. Struktura mieszkańców pod względem płci jest zbliżona w państwach europejskich i wskazuje na udział kobiet w populacjach mieszkańców od $50 \%$ do 54\% w państwach bałtyckich. Różnice natomiast dotyczą poziomu ich wykształcenia, dostęp do wszystkich stanowisk czy aktywność zawodową. $Z$ punktu widzenia prowadzonej analizy pod uwagę wzięto udział kobiet w zasobach ludzkich dla nauki i techniki..

Przeprowadzona analiza wskazuje, że możemy mówić o pojawiających się korelacjach pomiędzy stopniem feminizacji zasobów ludzkich dla nauki i techniki a poziomem aktywności patentowej, częściej dodatnich (również w odniesieniu do istotnych statystycznie), jednak ze względu na ich zróżnicowanie trudno o wskazanie generalnych prawidłowości.

\section{Model innowacyjności uwzględniający zmienną demograficzną}

Kolejną możliwą do wychwycenia zmienną demograficzną jest wiek. W niniejszym ujęciu pod uwagę wzięto cztery podejścia proponowane przez EUROSTAT: medianę wieku, proporcję osób w wieku do 19 lat względem osób powyżej 19 lat, proporcję osób w wieku powyżej 65 lat względem osób w wieku 15-64 lat, proporcję osób w wieku powyżej 60 lat względem osób w wieku 20-59 lat. Pierwszą i ostatnią z nich wykorzystano w budowie modelu ekonometrycznego, który umożliwiłby wskazanie relacji pomiędzy aktywnością patentową a poziomem wybranych zmiennych. Model przyjął postać:

$$
\begin{gathered}
\Delta \log P A T_{i t}=\alpha^{\prime} i+\left(\rho_{1}-1\right)\left(\log P A T_{i t-1}-\delta_{1} \log G E R D_{i t-1}-\delta_{2} \log P E R S_{i t-1}-\right. \\
\left.\delta_{3} \log X_{i t-1}\right)+\beta_{4} \Delta \log G E R D_{i t}+\beta_{5} \Delta \log P E R S_{i t}+\beta_{6} \Delta \log X_{i t}+\xi_{i t}
\end{gathered}
$$

gdzie: $P A T_{i t} \quad-$ liczba patentów zgłoszonych przez rezydentów na terenie danego regionu $i \mathrm{w}$ przeliczeniu na liczbę mieszkańców w okresie $t$,

$G E R D_{i t}$ - wydatki brutto na działalność $\mathrm{B}+\mathrm{R}$ jako procent $\mathrm{PKB} \mathrm{w}$ regionie $i$ w okresie $t$,

$P E R S_{i t}$ - personel sektora $\mathrm{B}+\mathrm{R}$ według ekwiwalentu pełnego zatrudnienia w przeliczeniu na liczbę zatrudnionych w regionie $i$ w okresie $t$,

$X_{i t} \quad-$ wybrana zmienna demograficzna (mediana wieku MED, proporcja osób w wieku powyżej 60 lat do osób w wieku 20-59 STM) w regionie $i$ w okresie $t$.

W wyniku estymacji otrzymano wyniki prezentowane w tab. 2 .

Wartością dodaną względem innych dotychczasowych modeli aktywności patentowej [Furman, Porter, Stern 2000; Szajt 2010] było wykorzystanie zmiennych demograficznych. Okazały się one istotne w długim okresie. W obu przypadkach wskazują na słabsze względem oczekiwań zróżnicowanie poziomu innowacyjności na skutek 
Tabela 3. Wartości ocen parametrów modeli

\begin{tabular}{|l|c|c|c|}
\hline \multirow{2}{*}{ Zmienna } & \multirow{2}{*}{ Parametr } & \multicolumn{2}{|c|}{ Ocena parametru } \\
\cline { 3 - 4 } & & model I & model II \\
\hline$P A T_{i, t-1}$ & $\alpha_{1}$ & 0,893 & 0,892 \\
\hline$\triangle P E R S_{i, t}$ & $\beta_{2}$ & 0,314 & 0,313 \\
\hline$G E R D_{i, t-1}$ & $\delta_{1}$ & 1,044 & 1,037 \\
\hline$M E D_{i, t-1}$ & \multirow{2}{*}{$\delta_{3}$} & $-4,157$ & $-1,563$ \\
\hline$S T M_{i, t-1}$ & & \multicolumn{2}{|c|}{} \\
\hline
\end{tabular}

Źródło: opracowanie własne na podstawie danych Eurostat.

czynników demograficznych. Ocenione ujemnie parametry stojące przy zmiennych wyznaczonych na bazie mediany wieku oraz proporcji osób w wieku powyżej 60 lat do osób w wieku 20-59 wskazują na malejącą aktywność patentową społeczeństw starzejących się. Jest to zgodne z przekazami prezentowanymi w badaniach. Nie chodzi tu tyle o samą aktywność w ujęciu podażowym, ile popytowym, wynikającą z ograniczonej absorpcyjności starszych społeczności.

\section{Zakończenie}

Przeprowadzone badania wskazały, że zróżnicowanie poziomu innowacyjności $\mathrm{w}$ regionach europejskich nie jest zdeterminowane czynnikami demograficznymi w stopniu silnym aczkolwiek zauważalny jest wpływ wybranych czynników na tę innowacyjność. Wzrost poziomu wykształcenia istotnie wpływa na wzmocnienie innowacyjności regionów, dotyczy to zwłaszcza wzrostu liczby osób posiadających wykształcenie wyższe. W aspekcie struktury płci nie stwierdzono prawidłowości świadczących o wpływie tego czynnika na kształtowanie się innowacyjności regionalnej. Natomiast zauważalny jest wpływ starzenia się społeczeństwa na aktywność patentową. Wzrost średniego wieku mieszkańców jest zwykle spowodowany wydłużeniem ich życia, a co za tym idzie - zwiększeniem populacji. Jest zatem logiczne, iż wskaźnik wykorzystujący jako zmienną referencyjną liczbę mieszkańców będzie w tym przypadku malał. Drugą kwestią jest zmniejszenie absorpcyjności innowacji ze strony osób starszych, co powoduje relatywny spadek popytu na tego typu produkty. W efekcie spada również podaż mierzona w pewnym stopniu zgłaszanymi patentami. Wyniki otrzymane dzięki estymacji modelu aktywności patentowej zwiastują ograniczenie (relatywne) popytu na produkty nowe ze strony starzejących się społeczeństw, do których już dzisiaj zalicza się nie tylko Polska, ale i inne państwa europejskie. Być może jest to jeden z niedostrzegalnych wcześniej powodów tak dynamicznego rozwoju w gospodarkach wzrostowych - głównie azjatyckich w których społeczeństwa charakteryzują się średnim wiekiem blisko 10 lat niższym niż w Europie. Przekłada się to bezpośrednio na większą, mobilniejszą i bardziej 
chłonną grupę aktywnych zawodowo, stanowiącą o możliwościach szybkiego rozwoju gospodarki, także w zakresie kreowania innowacji.

\section{Literatura}

Furman J.L., Porter M.E., Stern S., 2000, The Determinants of National Innovative Capacity, NBER Working Paper No. 7876.

http://ec.europa.eu/eurostat/data/database, dostęp: 28.08.2017.

Janasz W., Kozioł K., 2007, Determinanty działalności innowacyjnej przedsiębiorstw, PWE, Warszawa.

Ostraszewska Z., Tylec A., 2017, Zasoby ludzkie, aktywa intelektualne i inwestycje przedsiębiorstw jako ,,motory” innowacyjności Polski - analiza w oparciu o subindeksy sumarycznego wskaźnika innowacyjności, Ekonomika i Organizacja Przedsiębiorstwa, nr 5 (808), s. 79-93.

Szajt M., 2010, Działalność badawczo-rozwojowa w kształtowaniu aktywności innowacyjnej w Unii Europejskiej, Wydawnictwo Politechniki Częstochowskiej, Częstochowa.

Szajt M., 2013a, Potencjat kapitalu intelektualnego a wzrost gospodarczy regionów, Prace Naukowe Uniwersytetu Ekonomicznego we Wrocławiu, nr 285, s.144-156.

Szajt M., 2013b, Przestrzenno-czasowa analiza aktywności patentowej regionów Unii Europejskiej, Prace Komisji Geografii Przemysłu Polskiego Towarzystwa Geograficznego, nr 30(3), 191-104.

Turek I., 2016, Wiedza i innowacje jako kluczowe czynniki w rozwoju przedsiębiorczości. Przedsiębiorczość i zarządzanie, tom XVII, zeszyt 9, część II, s. 223-235.

Zawada M., Herbuś I., 2014, Innowacje droga do zintensyfikowania rozwoju województw, Zeszyty Naukowe Politechniki Częstochowskiej, Zarządzanie, nr 14, s. 35-45. 